\title{
Liposomal Rhenium Re 186
}

National Cancer Institute

\section{Source}

National Cancer Institute. Liposomal Rhenium Re 186. NCI Thesaurus. Code C107679.

A therapeutic preparation consisting of the beta-emitting radioisotope rhenium Re 186 encapsulated in a nanoliposome, with potential antineoplastic activity. Upon intratumoral infusion of liposomal rhenium Re 186, the radioisotope releases radiation, which directly kills the tumor cells. The nanoliposomes facilitate the retention of the radioisotope by the tumor cells and localize the radiocytotoxicity to the tumor while sparing surrounding normal, healthy cells. Re-186 has a short half-life and a short path length, which contributes further to limiting the radiotoxicity to the tumor cells. 